NISTIR 7325

\title{
Linear-Fit-Based Rating Procedure for Mixed Air- Source Unitary Air Conditioners and Heat Pumps Operating in the Cooling Mode
}

W. Vance Payne Piotr A. Domanski

U.S. DEPARTMENT OF COMMERCE National Institute of Standards and Technology Building Environment Division Building and Fire Research Laboratory Gaithersburg, Maryland 20899-8631

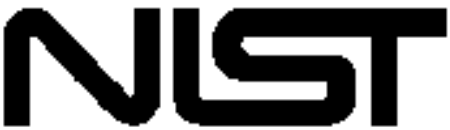

National Institute of Standards and Technology

Technology Administration United States Department of Commerce 



\section{Linear-Fit-Based Rating Procedure for Mixed Air- Source Unitary Air Conditioners and Heat Pumps Operating in the Cooling Mode}

W. Vance Payne Piotr A. Domanski

U.S. DEPARTMENT OF COMMERCE National Institute of Standards and Technology Building Environment Division Building and Fire Research Laboratory Gaithersburg, Maryland 20899-8631

June 2006

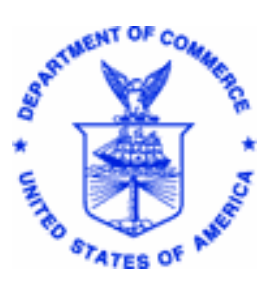

U.S. DEPARTMENT OF COMMERCE

Carlos M. Gutierrez, Secretary TECHNOLOGY ADMINISTRATION Michelle O'Neill, Acting Under Secretary of Commerce for Technology National Institute of Standards and Technology William Jeffrey, Director 


\section{Use of Non-SI Units in a NIST Publication}

It is the policy of the National Institute of Standards and Technology to use the International System of Units (metric units) in all of its publications. However, in North America in the HVAC\&R industry, non-SI units are so widely used instead of SI units that it is more practical and less confusing to include measurement values in customary units followed by SI units. 


\section{ACKNOWLEDGMENTS}

Brian Dougherty at NIST reviewed the procedure and provided the input for the calculation of SEER using the EER ratio, and he also provided his work on cyclic degradation coefficients, which was included in the calculation of the expansion device/time delay correction factor. Stefan Leigh of the NIST Statistical Engineering Division and his associates provided gracious assistance in reviewing the uncertainty analysis. The authors also thank Carl Bergt of Rheem Manufacturing Company, Chad Kirkwood of United Technologies/Carrier, Darryl Denton of American Standard/Trane, Mark Olsen of Lennox Industries, Ray Patil of Aspen Manufacturing, and Bob Magee formerly of Allstyle Coil Company for their reviews and technical input.

Thanks also to Michael Woodford of ARI for his organizational support and dissemination of the many drafts to the ARI Unitary Small Equipment Committee, whose membership also provided comments.

The U.S. Department of Energy, Building Technologies Program, Energy Efficiency and Renewable Energy supported the development of this rating procedure with Michael Raymond serving as the project manager. 
Concept of the Linear-Fit-Based Rating Procedure 1

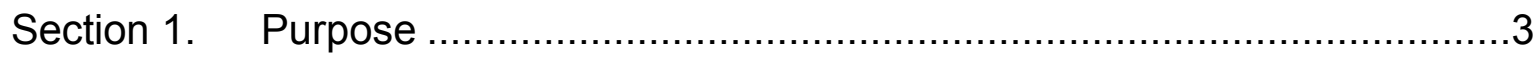

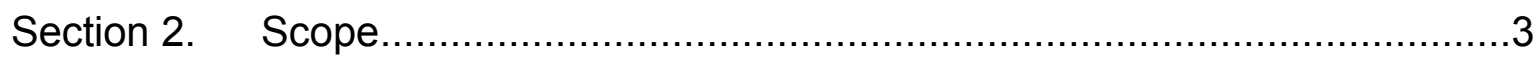

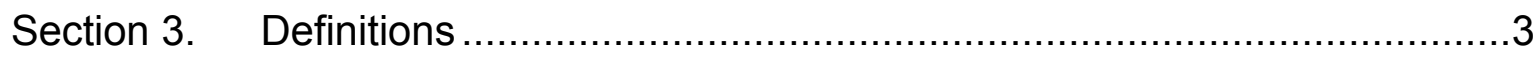

Section 4. Procedure for Rating a Mixed System ….................................. 4

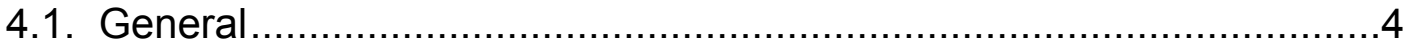

4.2. Mixed Indoor Section Data ...................................................

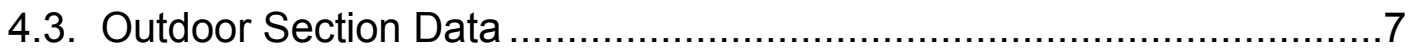

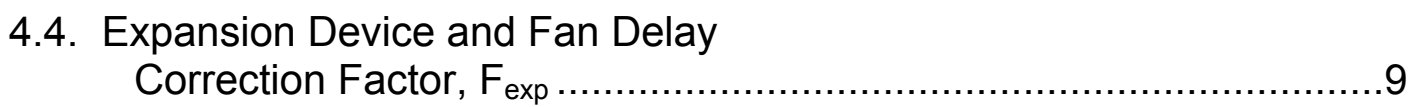

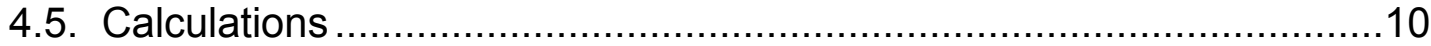

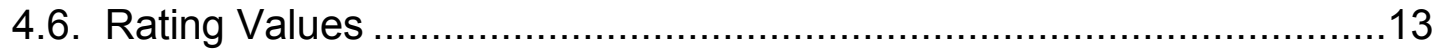

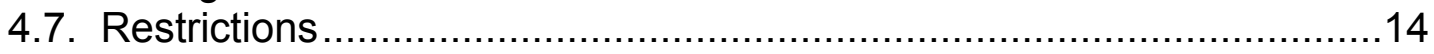

\section{TABLES}

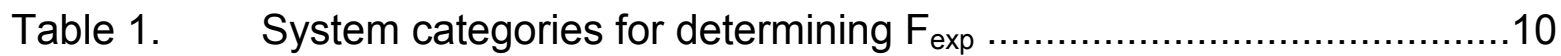

Table 2. $\quad F_{\text {exp }}$ for various mixed and matched system combinations ...............10

Table 3. Rated cooling capacity multiples..............................................14

Table C1. EER uncertainty for given uncertainties in capacity and power .........23

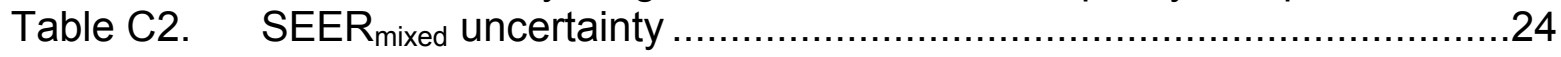

\section{FIGURES}

Figure 1. Graphical illustration of the linear fit based rating procedure............... 2

Figure $\mathrm{C} 1$. Uncertainty of mixed system capacity due to linear fit uncertainties .....19 Figure $\mathrm{C} 2$. Uncertainty of mixed system condensing unit power due to linear fit uncertainties

\section{APPENDICES}

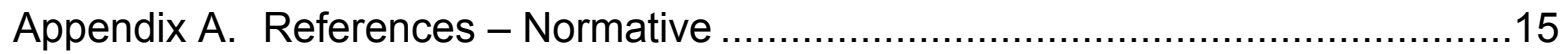

Appendix B. References - Informative ......................................................16

Appendix C. Uncertainty of the mixed system capacity and SEER ......................18 


\section{CONCEPT OF THE LINEAR-FIT-BASED RATING PROCEDURE}

A given single-speed, split system outdoor unit (consisting of a condenser, compressor, associated tubing, and, for heat pumps, a heating mode expansion device) can be installed with one of several different indoor units (consisting of the indoor coil, indoor fan, and expansion device). For each split system combination, the consumer is provided performance information - including the Seasonal Energy Efficiency Ratio (SEER) and the cooling capacity at the $95^{\circ} \mathrm{F}\left(35^{\circ} \mathrm{C}\right)$ rating point, $Q(95)$. Federal regulations require that the SEER rating for each model of outdoor section, when installed with its highest sales volume indoor section, be obtained from laboratory tests of the complete system (CFR 2006a). This tested highest sales volume combination is referred to here as the matched system. For all other combinations of indoor units with the same outdoor unit, the system ratings may be obtained by conducting the same set of laboratory tests or, in lieu of conducting system testing, by using a DOE approved methodology called an alternative rating method (ARM). Untested combinations whose ratings are determined using an ARM are called mixed systems. Mixed systems may be created using indoor units and outdoor units provided by the same manufacturer referred to as the system or original equipment manufacturer (OEM) - or created by using a third party indoor coil from an independent coil manufacturer (ICM).

One of the more commonly used ARM's for rating mixed systems relies upon the publicly available $Q(95)$ and SEER of the tested matched system (e.g., Domanski 1989). This (and other) ARM's require the rater to determine the cooling capacity of the matched system indoor coil. For an independent coil manufacturer, this requirement can be a major hurdle because of limits on the availability of specification data on the matched indoor coil and, if used, the accuracy of capacity prediction algorithms or computer simulation models. Any error in the matched indoor coil capacity propagates to affect the error in the mixed system SEER and Q(95) ratings. Consequently, an alternative rating method that does not include this step - such as the linear-fit-based method (L-F Method) - has the inherent potential of providing more accurate ratings.

Figure 1 shows the application of the L-F Method in graphical form for the cooling mode. This method uses a linear fit of the mixed indoor coil cooling capacity as a function of the evaporator exit refrigerant saturation temperature when the coil is subjected to standard operating conditions. The method also uses linear fits of cooling capacity and power consumption of the outdoor/condensing (CD) unit as a function of evaporator exit refrigerant saturation temperature when operated at the standard test conditions associated with the A Test of the DOE air conditioner and heat pump test procedure. The suction refrigerant saturation temperature for these fits is evaluated based on the pressure at the exit of the evaporator, or comparably, the inlet to the compressor. The $C D$ unit cooling capacity and power consumption linear fits are depicted in Figure 1 as $q(95)$ and $p(95)$ (A Test). Overlaying the indoor unit (evaporator) and CD Unit capacity line yields an intersection point that indicates the mixed system capacity (without indoor fan contributions) at the $A$ Test conditions $\left(95^{\circ} \mathrm{F}, 35.0^{\circ} \mathrm{C}\right)$. By projecting the refrigerant saturation temperature that corresponds to the A Test capacity onto the CD Unit power consumption plot, the power requirement for the $\mathrm{CD}$ Unit at the $95^{\circ} \mathrm{F}\left(35^{\circ} \mathrm{C}\right)$ rating 
point is determined. Although Figure 1 is convenient for explaining the L-F Method, this method is best implemented numerically using a computer.

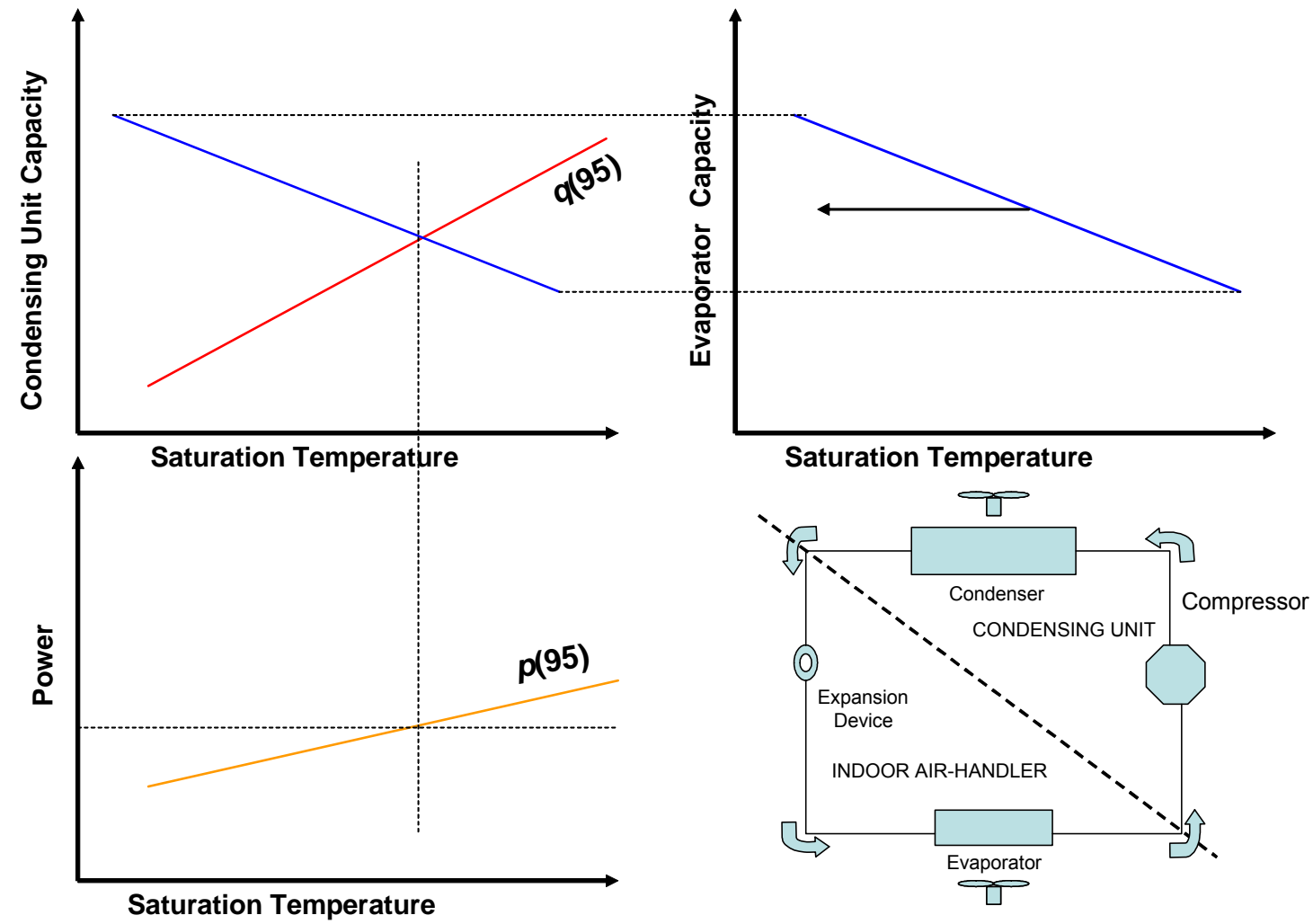

Figure 1. Graphical illustration of the linear fit based rating procedure

The rating process explained above does not account for indoor fan power. To finalize the rating of the mixed system, heat from the indoor fan must be included, thus reducing the cooling capacity, $q(95)$, obtained from overlaying the capacity lines of the CD Unit and mixed evaporator. The result is the actual mixed system capacity, $Q(95)$. Also, the indoor fan power must be added to the CD Unit power to produce the total power for the system, $P(95)$. The energy efficiency ratio at the A Test rating point, EER(95), can then be calculated.

$$
\operatorname{EER}(95)=\frac{Q(95)}{P(95)}
$$

To conclude with the SEER calculation of the mixed system, a value of expansion device correction factor for the mixed system is required.

$$
\mathrm{SEER}_{\text {mixed }}=\mathrm{SEER}_{\text {matched }} \frac{\operatorname{EER}(95)_{\text {mixed }}}{\operatorname{EER}(95)_{\text {matched }}} \mathrm{F}_{\text {exp }}
$$


EER(95) matched is used in the SEER calculation because it may be calculated from the rated cooling capacity which is readily available to mixed system coil manufacturers. $\operatorname{EER}(82)$ is preferable for this calculation, but this value is not readily available.

The expansion device correction factor must be obtained from a separate analysis.

\section{PURPOSE}

The purpose of this report is to establish the method for determining the cooling performance ratings of air-source unitary split system air conditioners and heat pumps consisting of an outdoor section and an indoor section that were not tested together as a complete system. The quantities calculated in this document are the cooling capacity at the A Test conditions and the SEER as prescribed by the U.S. Department of Energy in Appendix $M$ to Subpart B of Part 430 within Title 10 of the Code of Federal Regulations (CFR 2006a and CFR 2006b) and by ARI Standard 210/240 (ARI 2006).

\section{SCOPE}

This procedure applies to split system residential air-source unitary air conditioners and heat pumps. The outdoor section is characterized by a single-speed compressor with single-phase, electric power usage. The A Test cooling capacity of the highest sales volume combination used in obtaining the ratings of the mixed system shall be less than $65000 \mathrm{Btu} / \mathrm{h}(19050 \mathrm{~W})$. This procedure does not apply to systems employing multispeed compressors or using a load following control strategy (e.g., cylinder unloading, hot-gas bypass).

\section{DEFINITIONS}

All definitions cited in the Code of Federal Regulations, Subpart A, Part 430.2 (CFR 2006c) shall be considered a part of this procedure in addition to the following definitions.

A Test: pertaining to data collected according to DOE specified procedures and the following environmental conditions: $95^{\circ} \mathrm{F}\left(35^{\circ} \mathrm{C}\right)$ outdoor dry-bulb temperature, $80.0^{\circ} \mathrm{F}$ $\left(26.7^{\circ} \mathrm{C}\right)$ indoor dry-bulb temperature, and $67.0^{\circ} \mathrm{F}\left(19.4^{\circ} \mathrm{C}\right)$ indoor wet-bulb temperature (CFR 2006a, ARI 2006).

Air Source Unitary Air Conditioner or Air Source Unitary Heat Pump or Unitary System: an outdoor unit combined with an indoor coil assembly designed to function together as an air conditioning (and heating) system.

B Test: pertaining to data collected according to DOE specified procedures and the following environmental conditions: $82.0^{\circ} \mathrm{F}\left(27.8^{\circ} \mathrm{C}\right)$ outdoor dry-bulb temperature, $80.0^{\circ} \mathrm{F}\left(26.7^{\circ} \mathrm{C}\right)$ indoor dry-bulb temperature, and $67.0^{\circ} \mathrm{F}\left(19.4^{\circ} \mathrm{C}\right)$ indoor wet-bulb temperature(CFR 2006a, ARI 2006).

EER: Energy Efficiency Ratio defined as the cooling capacity divided by the total power input. 
Highest Sales Volume Tested Combination: System combination of outdoor condensing unit or heat pump outdoor unit that is the most likely to be sold. This is the combination that is laboratory tested per requirements in CFR Part 430.

Indoor Section: an assembly consisting of an interior/indoor refrigerant-to-air heat exchanger, condensate collection pan, and refrigerant expansion device, and which may include a blower, blower motor, and associated cabinet.

Indoor Fan Power: power (watts) measured at the indoor unit for the included fan. If no fan is included, the default value for indoor fan power (and heat) is $0.365 \mathrm{~W} / \mathrm{scfm}$ $\left(775 \mathrm{~W} /\left(\mathrm{m}^{3} / \mathrm{s}\right)\right)$. Rated cooling capacity must always include the measured or default fan heat. Cooling capacity linear-fits do not include the indoor fan heat.

Matched Coil: an indoor coil which is part of the matched system.

Matched System: a unitary system which has been tested and rated in accordance with federal regulations.

Mixed Coil: an indoor coil which is part of the mixed system.

Mixed System: a unitary system which is not tested as a complete system in accordance with federal regulations but instead has its SEER and rated cooling capacity determined using a DOE-approved alternative rating method.

Outdoor Section: an assembly of components designed to compress and/or liquefy a specific refrigerant and located in the exterior/outdoor environment. It consists of at least a refrigerant vapor compressor, refrigerant-to-air heat exchanger, motorized fan, refrigerant vapor and liquid lines, and other standard components.

Shall: where "shall" or "shall not" are used for a specified provision, that provision is mandatory if compliance with the procedure is claimed.

Should, Recommended, or It Is Recommended: "should", "recommended", or "it is recommended" are used to indicate provisions which are not mandatory but which are desirable as good practice.

\section{PROCEDURE FOR RATING A MIXED SYSTEM}

\subsection{General}

Below are the basic steps required when rating a mixed air conditioner using the L-F Method.

- Obtain data for the matched system: SEER, Q(95), and the following information on the matched system indoor unit - type of expansion device, whether using a liquid line solenoid, whether equipped with an indoor fan delay. If the evaporator 
is a blower coil, the rater should obtain the power draw of the indoor fan when providing the rated $\mathrm{Q}(95)$

- Obtain or develop data for the outdoor section (condensing unit)

- Outdoor section capacity linear fit at the A Test conditions as a function of the evaporator exit refrigerant saturation temperature

- Outdoor section power linear fit at the A Test conditions as a function of the evaporator exit refrigerant saturation temperature

- Obtain or develop data for the mixed indoor section

o Indoor coil capacity linear fit as a function of the evaporator exit refrigerant saturation temperature at indoor air conditions of $80.0^{\circ} \mathrm{F}\left(26.7^{\circ} \mathrm{C}\right) \mathrm{dry}-\mathrm{bulb} /$ $67.0^{\circ} \mathrm{F}\left(19.4^{\circ} \mathrm{C}\right)$ wet-bulb temperatures

0 Indoor fan power

- Determine the expansion device and fan delay correction factor for the mixed system

- Perform rating calculations

These steps are detailed in the following sections.

\subsection{Mixed Indoor Section Data}

\subsubsection{Correlation for indoor coil capacity}

The correlation for indoor coil capacity shall have the following form:

$$
q_{\text {coil }}=\mathrm{C}_{\text {coil }}+\mathrm{D}_{\text {coil }} \cdot T_{\text {evap }}
$$

where $q_{\text {coil }}$ - indoor coil cooling capacity at $80.0^{\circ} \mathrm{F}\left(26.7^{\circ} \mathrm{C}\right)$ dry-bulb/67.0 ${ }^{\circ} \mathrm{F}\left(19.4^{\circ} \mathrm{C}\right)$ wet-bulb air temperature and at a manufacturer-specified air volume rate, without indoor fan heat, Btu/h (W)

$\mathrm{C}_{\text {coil }}$ - linear intercept, Btu/h (W)

$\mathrm{D}_{\text {coil }}$ - linear slope, $\mathrm{Btu} /\left(\mathrm{h}^{\circ} \mathrm{F}\right)\left(\mathrm{W} /{ }^{\circ} \mathrm{C}\right)$

$T_{\text {evap }}$ - refrigerant saturation temperature at the evaporator exit, ${ }^{\circ} \mathrm{F}\left({ }^{\circ} \mathrm{C}\right)$

Equation 4.1 shall be determined using capacities from laboratory tests, or in lieu of laboratory tests, from simulations using a validated simulation model, or from a combination of experimental and simulation results. The same refrigerant shall be used to rate the mixed system and the matched system.

\subsubsection{Determination of Equation 4.1 coefficients using laboratory test data}

The constants in Equation 4.1 shall be determined by fitting the measured coil cooling capacities and exit refrigerant saturation temperatures using the least-squares method. 
The indoor coil tests shall be carried out in accordance with the procedures set forth in ASHRAE Standard 33 and indoor air conditions corresponding to the A and B Tests. The following parameters shall be controlled within the specified ranges:

- The airflow shall match the intended coil application. The volumetric air flow shall not exceed $450 \mathrm{scfm} / \mathrm{ton}\left(217.4 \mathrm{~m}^{3} / \mathrm{kW}\right)$ and, for coil-only indoor units, the maximum static air pressure drop measured across the coil may not exceed 0.30 in $\mathrm{H}_{2} \mathrm{O}$ gage (75.0 Pa gage).

- The refrigerant entering the expansion device shall be liquid at a temperature normally seen with condensing units with which the mixed indoor coil would be paired, with a minimum of $7.5^{\circ} \mathrm{F}\left(4.2^{\circ} \mathrm{C}\right)$ subcooling. The liquid temperature used for a particular linear fit shall not vary more than $\pm 5.0^{\circ} \mathrm{F}\left( \pm 2.8^{\circ} \mathrm{C}\right)$ from the average value for all experimental data used to generate the linear fit.

- The refrigerant superheat at the evaporator exit shall be $10.0^{\circ} \mathrm{F} \pm 5.0^{\circ} \mathrm{F}$ $\left(5.0^{\circ} \mathrm{C} \pm 2.8^{\circ} \mathrm{C}\right)$.

The tests shall be performed at different evaporator exit refrigerant saturation temperatures to cover the expected saturation temperature range of the mixed system, which typically neither extends below $40.0^{\circ} \mathrm{F}\left(4.4^{\circ} \mathrm{C}\right)$ nor exceeds $52.0^{\circ} \mathrm{F}\left(11.1^{\circ} \mathrm{C}\right)$. It is recommended that the range of evaporator refrigerant saturation temperatures for which the linear fit may be applied and the percentage uncertainty of the capacity $( \pm x \%)$ be reported along with the coefficients developed for Equation 4.1. Appendix C presents an example uncertainty calculation that may aid in the development of percentage uncertainties.

4.2.1.2 Determination of Equation 4.1 coefficients using analytical predictions of coil cooling capacity

The constants in Equation 4.1 shall be determined by fitting a line to the predicted coil cooling capacities for at least two different evaporator exit refrigerant saturation temperatures.

Airflow and temperature parameters shall be as specified above in Section 4.2.1.1. All simulations shall be performed with a validated simulation tool. Refer to Section 4.7 for simulation tool validation requirements.

\subsubsection{Indoor fan power and heat}

If a fan is used with the mixed indoor section, its electrical power shall be measured with an uncertainty of $\pm 1 \%$ (for a single measurement). If a fan is not included with the indoor coil, the default indoor fan power shall be calculated by the following equation:

$$
P_{\text {fan,mixed }}=W_{\mathrm{f}} \cdot V_{\text {ind }}
$$

where: $\quad W_{\mathrm{f}}=$ flow specific fan power multiplier of $0.365 \mathrm{~W} / \mathrm{scfm}\left(775 \mathrm{~W} /\left(\mathrm{m}^{3} / \mathrm{s}\right)\right)$

$V_{\text {ind }}=$ indoor air volume rate of standard air, $\mathrm{scfm}\left(\mathrm{m}^{3} / \mathrm{s}\right)$ 
The heat added to the air stream shall be calculated by Equation 4.3:

$$
Q_{\text {fan,mixed }}=W_{c} \cdot P_{\text {fan,mixed }}
$$

where: $\quad W_{c}=3.412 \mathrm{Btu} /(\mathrm{W} \cdot \mathrm{h})(1 \mathrm{~W} / \mathrm{W})$

\subsection{Outdoor Section Data}

Outdoor section cooling capacity and power shall be represented by linear functions of the evaporator exit refrigerant saturation temperature. The linear fit coefficients shall be determined from a least-squares fit at different evaporator exit refrigerant saturation temperatures. At least one of the data points shall be the average tested value of the highest sales volume tested combination (HSVTC) system. All linear fits shall be adjusted to pass through the average test data point for the HSVTC system. Measurements and calculations of system performance shall be made according to ARI 210/240 (ARI 2006).

\subsubsection{Correlation for outdoor section cooling capacity at A Test conditions}

The correlation for the outdoor section cooling capacity at the A Test conditions shall have the following form:

$$
q_{C D}(95)=C_{C D}(95)+D_{C D}(95) \cdot T_{\text {evap }}
$$

where $\quad q_{\mathrm{CD}}$ - outdoor section capacity at the A (95) Test conditions, without indoor fan heat, Btu/h (W)

$\mathrm{C}_{\mathrm{CD}}$ - outdoor section capacity linear intercept at the $\mathrm{A}(95)$ Test conditions, Btu/h (W)

$D_{C D}$ - outdoor section capacity linear slope at the A (95) Test conditions, $\mathrm{Btu} /\left(\mathrm{h}^{\circ} \mathrm{F}\right)\left(\mathrm{W} /{ }^{\circ} \mathrm{C}\right)$

$T_{\text {evap }}$ - refrigerant saturation temperature at the evaporator exit, ${ }^{\circ} \mathrm{F}\left({ }^{\circ} \mathrm{C}\right)$

Equation 4.4 coefficients shall be determined using capacities from laboratory tests, from simulations using a validated simulation model, or from a combination of experimental and simulation results. At least one of the data points shall be from the laboratory data utilizing the HSVTC system.

\subsubsection{Determination of Equation 4.4 coefficients using laboratory test data}

The constants in Equation 4.4 shall be determined by fitting the measured outdoor section cooling capacities and evaporator exit refrigerant saturation temperatures using the least-squares method.

The test conditions shall be those specified for the DOE A Test (CFR 2006a, ARI 2006). The pressure used to calculate $T_{\text {evap }}$ shall be the measured or simulated refrigerant 
pressure at the outlet of the evaporator. Simulations shall use the method presented in ASHRAE 2002 to predict the refrigerant pressure drop in the suction line from the evaporator outlet to the compressor inlet if this is needed to determine the evaporator exit refrigerant saturation pressure.

The tests shall be performed at different evaporator exit refrigerant saturation temperatures, which typically do not extend below $40.0^{\circ} \mathrm{F}\left(4.4^{\circ} \mathrm{C}\right)$ and do not exceed $52.0^{\circ} \mathrm{F}\left(11.1^{\circ} \mathrm{C}\right)$.

The following information shall be reported for Equation 4.4 in addition to the linear slope and intercept coefficients:

- The average liquid line temperature for the $q(95)$ linear fit

- The type of cooling mode expansion device used (non-bleed TXV, bleed-type $\mathrm{TXV}$, electronic expansion device, capillary tube, or short tube)

It is also recommended that the range of refrigerant evaporator temperatures for which the linear fit is applicable along with the linear fit percentage uncertainty $( \pm x \%)$ be reported.

4.3.1.2. Determination of Equation 4.4 coefficients using a combination of experimental data and analytical predictions

This rating procedure allows using a combination of experimental data and analytical methods for determination of Equation 4.4 coefficients provided that the performance predictions will be equivalent to those obtained when steps described in sections 4.3.1.1 are followed.

One example of combining laboratory test and simulation results may be using an experiment to obtain outdoor section performance at a small range of evaporator exit refrigerant saturation temperatures, and extrapolating these data to a wider range of saturation temperatures with a simulation model. All quantities reported in Section 4.3.1.1 shall still be reported if this technique is used.

All simulations shall be performed with a validated simulation tool. Refer to Section 4.7 for simulation tool validation requirements.

\subsubsection{Correlation of outdoor section power at A Test conditions}

Outdoor unit power at the A Test conditions shall be represented by a linear fit of the following form:

$$
p_{\mathrm{CD}}(95)=\mathrm{E}_{\mathrm{CD}}(95)+\mathrm{F}_{\mathrm{CD}}(95) \cdot T_{\text {evap }}
$$

where: $p_{\mathrm{CD}}(95)$ - outdoor section total power without indoor fan power, $\mathrm{W}$ 
$E_{C D}(95)$ - outdoor section power linear intercept at the A Test conditions, W

$\mathrm{F}_{\mathrm{CD}}(95)$ - outdoor section power linear slope at the A Test conditions, $\mathrm{W} /{ }^{\circ} \mathrm{F}$

$\left(\mathrm{W} /{ }^{\circ} \mathrm{C}\right)$

Equation 4.5 coefficients shall be determined using capacities from laboratory tests or from a combination of experimental and simulation results. At least one of the data points shall be from the laboratory data utilizing the HSVTC system.

\subsubsection{Determination of Equation 4.5 coefficients using laboratory test data}

Outdoor section power shall be measured with an uncertainty not to exceed $\pm 1 \%$ (for a single measurement). As noted previously, at least one of the data points shall be per the tested values of the HSVTC system. Power shall be the total power of the matched system excluding indoor fan power. This includes the compressor, outdoor fan, controls, and other ancillary equipment normally associated with the outdoor unit. Power measurements shall be taken concurrently with the laboratory measurements used to obtain cooling capacity data.

It is recommended that the percentage uncertainty of the condensing unit power $( \pm x \%)$ be reported along with the coefficients developed for Equation 4.5. The evaporator exit refrigerant saturation temperature range shall be the same as that reported for the $q(95)$ linear fit.

4.3.2.2. Determination of Equation 4.5 coefficients using a combination of experimental data and analytical predictions

The constants in Equation 4.5 shall be determined from a linear fit of predicted outdoor unit power at different evaporator exit refrigerant saturation temperatures. At least one of the data points shall be per the tested values of the HSVTC system. All quantities reported in Section 4.3.2.1 shall still be reported if this method is used. The resulting equation must be adjusted to pass through the HSVTC tested value as noted at the beginning of Section 4.3 .

The simulation tool shall be validated against experimental data obtained during the tests used to validate predictions of cooling capacity described in section 4.3.1.2. The validation shall demonstrate that the simulation tool can predict the outdoor section power and EER at the A Test conditions. Refer to Section 4.7 for general simulation tool validation requirements.

\subsection{Expansion Device and Fan Delay Correction Factor, $F_{\exp }$}

The value of the expansion device/fan delay correction factor for the mixed system shall be selected using the procedure described below. 
First, determine the mixed and matched system category from Table 1 (either A, B1, B2, or $\mathrm{C}$ ). Then, determine the $\mathrm{F}_{\exp }$ value using the system categories in Table 2 (Dougherty 2004).

Table 1. System categories for determining $F_{\text {exp }}$

\begin{tabular}{|c|c|c|c|}
\hline $\begin{array}{c}\text { System } \\
\text { Category }\end{array}$ & $\begin{array}{c}\text { System Pressure } \\
\text { Equalization } \\
\text { During Off Cycle }\end{array}$ & $\begin{array}{c}\text { Indoor Fan } \\
\text { Turn-Off Delay }\end{array}$ & System Components \\
\hline A & Yes & No & $\begin{array}{c}\text { Cap Tube } \\
\text { Orifice } \\
\text { Bleed TXV }\end{array}$ \\
\hline B1 & No & No & $\begin{array}{c}\text { Non-Bleed TXV } \\
\text { Electronic Expansion Device } \\
\text { Liquid Line Solenoid }\end{array}$ \\
\hline B2 & Yes & Yes & $\begin{array}{c}\text { Cap Tube } \\
\text { Orifice } \\
\text { Bleed TXV }\end{array}$ \\
\hline C & No & Yes & $\begin{array}{c}\text { Non-Bleed TXV } \\
\text { Electronic Expansion Device } \\
\text { Liquid Line Solenoid }\end{array}$ \\
\hline
\end{tabular}

Table 2. $F_{\text {exp }}$ for various mixed and matched system combinations

\begin{tabular}{|c|c|c|c|c|c|}
\hline \multicolumn{2}{|c|}{} & \multicolumn{4}{|c|}{ Matched System } \\
\cline { 3 - 6 } \multicolumn{2}{|c|}{} & A & B1 & B2 & C \\
\hline \multirow{3}{*}{$\begin{array}{c}\text { Mixed } \\
\text { System }\end{array}$} & A & 1.000 & 0.990 & 0.990 & 0.974 \\
\cline { 2 - 6 } & B1 & 1.010 & 1.000 & 1.000 & 0.985 \\
\cline { 2 - 6 } & B2 & 1.010 & 1.000 & 1.000 & 0.985 \\
\cline { 2 - 6 } & C & 1.026 & 1.016 & 1.016 & 1.000 \\
\hline
\end{tabular}

The rating procedure shall not be used for any system if the matched system has a TXV and the mixed system has either a capillary tube or a short tube expansion device, unless the condensing unit manufacturer also certifies a system in which the TXV is replaced by a capillary/short tube. If this is the case, the manufacturer's condensing unit system with the capillary/short tube may be considered as the matched system and its performance data used to calculate the performance of the mixed system.

The rater shall specify the mixed system capillary/short tube if this is the expansion device for the mixed system. If the mixed system capacity is similar to that of the matched system, specifying the same capillary/short tube as used in the matched system may be adequate. If the mixed and matched system capacities differ markedly, a validated engineering analysis, accounting for the different evaporator refrigerant pressures, shall be used to specify the mixed system capillary/short tube.

\subsection{Calculations}

4.5.1. Rated cooling capacity at A Test conditions, $Q_{\text {mixed }}(95)$ 
The indoor section cooling capacity must be corrected to the same refrigerant liquid temperature and evaporator exit refrigerant superheat for which the matched system capacity and power linear fits were generated. The corrections cannot be used for superheats lower than $5.0^{\circ} \mathrm{F}\left(2.8^{\circ} \mathrm{C}\right)$; therefore, if the matched condensing unit superheat was below $5.0^{\circ} \mathrm{F}\left(2.8^{\circ} \mathrm{C}\right)$, the correction values for a superheat of $5.0^{\circ} \mathrm{F}$ $\left(2.8^{\circ} \mathrm{C}\right)$ shall be used.

If the matched condensing unit evaporator exit refrigerant superheat is not known then the rater shall assume the following; if a TXV was used as the expansion device, the $q(95)$ linear fit average evaporator exit superheat shall be assumed to be $10.0^{\circ} \mathrm{F}$ $\left(5.6^{\circ} \mathrm{C}\right)$. If a short tube was used as the expansion device, evaporator exit superheat shall be assumed to be $5.0^{\circ} \mathrm{F}\left(2.8^{\circ} \mathrm{C}\right)$.

Step 1: Estimate the correction for the indoor section capacity equation, $\varepsilon_{1 \text { cor }}$

$$
\varepsilon_{\text {1cor }}=\left(\frac{T_{\text {liq, CD }}}{T_{\text {liq, Coil }}}\right)^{-0.123}\left(\frac{T_{\text {suph }, \mathrm{CD}}}{T_{\text {suph }, \mathrm{Coil}}}\right)^{-0.0879}
$$

where: $T_{\text {liq,CD }}$ - refrigerant liquid temperature as listed for the outdoor section at the $\mathrm{A}$

Test conditions $\left({ }^{\circ} \mathrm{F}\right)$

$T_{\text {suph,CD }}$ - refrigerant superheat at the evaporator exit as listed for the outdoor section at the A Test conditions ( $\left.{ }^{\circ} \mathrm{F}\right)$

$T_{\text {liq,Coil }}$ - refrigerant liquid temperature used during the generation of the linear fit for the indoor coil $\left({ }^{\circ} \mathrm{F}\right)$

$T_{\text {suph,Coil }}$ - refrigerant superheat at the evaporator exit used during the generation of the linear fit for the indoor coil $\left({ }^{\circ} \mathrm{F}\right)$

Step 2: Estimate the evaporator refrigerant saturation temperature at the A Test conditions, $T_{\text {evap }}(95)$

$$
T_{\text {evap }}(95)=\frac{\varepsilon_{1 \text { cor }} \cdot \mathrm{C}_{\text {coil }}-\mathrm{C}_{\mathrm{CD}}(95)}{\mathrm{D}_{\mathrm{CD}}(95)-\varepsilon_{\text {1cor }} \cdot \mathrm{D}_{\text {coil }}}
$$

Step 3: Improve the estimate of the correction for indoor section capacity equation, $\varepsilon_{2 \text { cor }}$

$$
\varepsilon_{2 \text { cor }}=\left(\frac{T_{\text {liq, CD }}}{T_{\text {liq, Coil }}}\right)^{b 1}\left(\frac{T_{\text {suph }, \mathrm{CD}}}{T_{\text {suph }, \mathrm{Coil}}}\right)^{b 2}
$$

where: $\quad \mathrm{b} 1=-0.123\left(\frac{T_{\text {evap }}(95)}{50}\right)$ 


$$
\mathrm{b} 2=-0.0879\left(\frac{T_{\text {evap }}(95)}{50}\right)
$$

$T_{\text {evap }}(95)$ - evaporator refrigerant saturation temperature calculated from Equation 4.7 , converted to ${ }^{\circ} \mathrm{F}$ (if calculated in ${ }^{\circ} \mathrm{C}$ )

Step 4: Calculate evaporator refrigerant saturation temperature at the $\mathrm{A}$ Test conditions, $T_{\text {evap }}(95)$

$$
T_{\text {evap }}(95)=\frac{\varepsilon_{2 \text { cor }} \cdot \mathrm{C}_{\text {coil }}-\mathrm{C}_{\mathrm{CD}}(95)}{\mathrm{D}_{\mathrm{CD}}(95)-\varepsilon_{2 \text { cor }} \cdot \mathrm{D}_{\text {coil }}}
$$

Step 5: Calculate mixed system capacity at the A Test conditions, $Q_{\text {mixed }}(95)$

$$
Q_{\text {mixed }}(95)=q_{C D}(95)-Q_{\text {fan,mixed }}=C_{C D}(95)+D_{C D}(95) \cdot T_{\text {evap }}(95)-Q_{\text {fan }, \text { mixed }}
$$

\subsubsection{Seasonal Energy Efficiency Ratio, SEER}

Calculation of the SEER requires the energy efficiency ratio at the A Test conditions for the mixed and matched systems, EER(95) mixed and EER(95) matched, respectively.

\subsubsection{1. $\operatorname{EER}(95)_{\text {mixed }}$ calculation}

The energy efficiency ratio is calculated using mixed system capacity $Q_{\text {mixed }}(95)$ and power $P_{\text {mixed }}(95)$.

$$
\begin{gathered}
\operatorname{EER}(95)_{\text {mixed }}=\frac{Q_{\text {mixed }}(95)}{P_{\text {mixed }}(95)} \\
P_{\text {mixed }}(95)=p_{\mathrm{CD}}(95)+P_{\text {fan,mixed }}=\mathrm{E}_{\mathrm{CD}}(95)+\mathrm{F}_{\mathrm{CD}}(95) \cdot T_{\text {evap }}(95)+P_{\text {fan, mixed }}
\end{gathered}
$$

where $Q_{\text {mixed }}(95)$ shall be taken from Equation 4.10.

$T_{\text {evap }}(95)$ shall be obtained from Equation 4.9.

\subsubsection{EER(95) matched_calculation}

The tested value of $\operatorname{EER}(95)_{\text {matched, }}$ with its associated uncertainty, shall be used if available; otherwise, the value of $\operatorname{EER}(95)_{\text {matched }}$ shall be calculated using the matched condensing unit capacity and power linear fits. This is done to eliminate the propagation of conservatively rated $\operatorname{EER}(95)_{\text {matched }}$ uncertainty into the calculation of SEER mixed. $_{\text {. }}$

$$
q_{\mathrm{CD}}(95)_{\text {matched }}=Q_{\mathrm{CD}}(95)_{\text {matched }}+Q_{\mathrm{fan}, \text { matched }}
$$




$$
\begin{gathered}
T_{\text {evap }}(95)_{\text {matched }}=\frac{q_{\mathrm{CD}}(95)_{\text {matched }}-\mathrm{C}_{\mathrm{CD}}(95)}{\mathrm{D}_{\mathrm{CD}}(95)} \\
\begin{array}{r}
P_{\text {matched }}(95)=p_{\mathrm{CD}}(95)+P_{\text {fan, matched }} \\
=\mathrm{E}_{\mathrm{CD}}(95)+\mathrm{F}_{\mathrm{CD}}(95) \cdot T_{\text {evap }}(95)_{\text {matched }}+P_{\text {fan, matched }}
\end{array}
\end{gathered}
$$

where $Q_{C D}(95)_{\text {matched }}=$ matched system tested (or rated is test data is not available) cooling capacity at A Test conditions $\mathrm{Q}_{\mathrm{fan}, \text { matched }}=$ matched system indoor fan heat in Btu/h (W) (calculated or determined from measured fan power)

$T_{\text {evap }}(95)_{\text {matched }}=$ calculated matched system evaporator exit refrigerant saturation temperature at the A Test conditions

$P_{\text {fan,matched }}=$ matched system indoor fan power (calculated from airflow rate or measured)

$$
\operatorname{EER}(95)_{\text {matched }}=\frac{Q_{\mathrm{CD}}(95)_{\text {matched }}}{P_{\text {matched }}(95)}
$$

\subsubsection{SEER calculation}

SEER shall be calculated using Equation 4.17. Ideally, EER(82) for the mixed and matched systems should be used in this calculation, but EER(95) for the matched system is more readily available. SEER $R_{\text {matched }}$ shall be the value certified by the matched system manufacturer.

$$
\mathrm{SEER}_{\text {mixed }}=\mathrm{SEER}_{\text {matched }} \frac{\operatorname{EER}(95)_{\text {mixed }}}{\operatorname{EER}(95)_{\text {matched }}} \mathrm{F}_{\text {exp }}
$$

\subsection{Rating Values}

The rater is responsible for all ratings obtained when using this procedure. The calculated ratings are strongly influenced by the input data, and particularly, by the goodness of the power and capacity linear fits (Payne and Domanski 2005). Therefore, the rater shall establish the acceptability of the input data, including all linear fits, before these data are used for ratings.

\subsubsection{Reported cooling capacity at the A Test Conditions $\left(Q_{\text {mixed }}(95)\right)$}

The rated cooling capacity $Q_{\text {mixed }}(95)$ shall be expressed in Btu/h (W) in multiples of the quantities listed in Table 3. 
Table 3. Rated cooling capacity multiples

\begin{tabular}{|c|c|}
\hline Cooling capacity, Btu/h (W) & Multiples, Btu/h (W) \\
\hline$Q_{\text {mixed }}(95)<20000(5900)$ & $100(30)$ \\
\hline $20000(5900) \leq Q_{\text {mixed }}(95)<38000(11000)$ & $200(60)$ \\
\hline $38000(11000) \leq Q_{\text {mixed }}(95)<65000(19000)$ & $500(150)$ \\
\hline \multicolumn{2}{|c|}{$Q_{\text {mixed }}(95)$ shall not exceed the value calculated using the applicable equation. } \\
\hline
\end{tabular}

\subsubsection{Reported SEER}

SEER shall be expressed in multiples of 0.05 not to exceed the value calculated by Equation 4.17.

\subsection{Restrictions}

If the rating is calculated for a heat pump system able to operate in the heating mode, the following two conditions should be satisfied (Domanski 1989): 1) The internal volume of the mixed indoor coil assembly should be within $100 \%$ to $120 \%$ of the internal volume of the matched coil or should not exceed the volume of the largest coil certified with a given condensing unit by the condensing unit manufacturer, whichever is larger. 2) Condensing capacity of the mixed coil should be within $100 \%$ to $120 \%$ of the capacity of the matched coil, or should not exceed the capacity of the largest certified coil, whichever is larger.

Verification of simulation tools requires that the method predicts capacity (A Test) within $5 \%$ of the measured values for systems having the smallest and largest indoor units for which the verification tool will be applied. For example, if a manufacturer produces a coil family having capacities ranging from $12000 \mathrm{Btu} / \mathrm{h}(3516.9 \mathrm{~W})$ to $28000 \mathrm{Btu} / \mathrm{h}$ $(8206.0 \mathrm{~W})$ and uses a simulation tool to predict the capacities, the simulation tool must be within $5 \%$ agreement with the test values of the smallest capacity coil and largest capacity coil.

A coil simulation model shall be able to account for coil design variations such as tube diameter, tube pitch, depth pitch, heat transfer surfaces on the refrigerant and air sides, etc., and it should be validated for each coil family. For the purpose of this rating procedure, a coil family is a group of coils with the same basic design features that affect the heat exchanger performance (i.e. A-shape, V-shape, slanted or flat top, heat exchanger surfaces, tube sizes, construction material, see CFR 2006c).

The same validation approach, as explained above for capacity, shall be applied to power prediction tools. 


\section{APPENDIX A. REFERENCES - NORMATIVE}

ANSI/ASHRAE 2005. ANSI/ASHRAE Standard 37. Methods of testing for rating unitary air conditioning and heat pump equipment. American Society of Heating, Refrigerating and Air-Conditioning Engineers. 1791 Tullie Circle NE, Atlanta, GA, 30329 USA.

ASHRAE 1991. ASHRAE terminology of heating, ventilation, air conditioning, and refrigeration, $2^{\text {nd }}$ Edition, American Society of Heating, Refrigerating and AirConditioning Engineers. 1791 Tullie Circle NE, Atlanta, GA, 30329 USA.

ASHRAE 2002. ASHRAE Handbook: Refrigeration, Chapter 2, American Society of Heating, Refrigerating and Air-Conditioning Engineers. 1791 Tullie Circle NE, Atlanta, GA, 30329 USA, page 2.3.

ARI 2006. Standard 210/240, Standard for unitary air-conditioning and air-source heat pump equipment, Air-Conditioning and Refrigeration Institute, 4100 North Fairfax Drive, Suite 200, Arlington, VA 22203.

CFR, 2006a. Code of Federal Regulations, Title 10 (Department of Energy), Chapter 2, Part 430.23, Subpart B, Appendix M, "Uniform test method for measuring the energy consumption of central air conditioners," U.S. Government Printing Office, Washington, DC.

CFR, 2006b. Code of Federal Regulations, Title 10, Chapter 2, Part 430.24, Subsection m1, "Units to be tested," U.S. Government Printing Office, Washington, DC.

CFR, 2006c. Code of Federal Regulations, Part 430.2, Definitions, U.S. Government Printing Office, Washington, DC.

Domanski, P.A., 1989. Rating procedure for mixed air-source unitary air conditioners and heat pumps operating in the cooling mode - revision 1, NISTIR 89-4071, U. S. Dept of Commerce, Natn'l Institute of Standards and Technology, Gaithersburg, Maryland USA 20899. 


\section{APPENDIX B. REFERENCES - INFORMATIVE}

ASHRAE 2000. ASHRAE Standard 33-2000. MOT Forced circulation air cooling and air heating coils, American Society of Heating, Refrigerating and Air-Conditioning Engineers. 1791 Tullie Circle NE, Atlanta, GA, 30329 USA.

ARI 2001. Standard 410, Standard for forced-circulation air-cooling and air-heating coils, Air-Conditioning and Refrigeration Institute, 4100 North Fairfax Drive, Suite 200, Arlington, VA 22203.

Code of Federal Regulations 2006. Web Link. http://www.access.gpo.gov/nara/cfr/cfrtable-search.html\#page1

Code of Federal Regulations, Part 430 2006. Web Link. http://www.access.gpo.gov/nara/cfr/waisidx_05/10cfr430_05.html

Coleman, H.W. and Steele, W.G., 1989. Experimentation and uncertainty analysis for engineers, John Wiley and Sons, New York, NY USA.

Domanski, P.A., 1999. "Finned-Tube Evaporator Model With a Visual Interface", $20^{\text {th }}$ Int. Congress of Refrigeration, Sydney, Australia, September 19-24, 1999, International Institute of Refrigeration, Paris.

Dougherty, B., 2004. Personal communications, National Institute of Standards and Technology, Gaithersburg, Maryland, USA, 20899-8632.

Graybill, F. A. and lyer, H. K., 1994. Regression Analysis: Concepts and Applications, Duxbury Press, Wadsworth Publishing Company, Belmont, California USA 94002, pp. 194-209.

Lemmon, E. W., McLinden, M. O., and Huber, M. L., 2002. NIST Standard Reference Database 23: NIST Reference Fluid Thermodynamic and Transport Properties REFPROP, Version 7, U. S. Dept of Commerce, Natn'l Institute of Standards and Technology, Gaithersburg, Maryland USA 20899.

Moffat, R. 1988. Describing the uncertainties in experimental results. Experimental Thermal and Fluid Science. Vol. 1. pp. 3-17.

Neter J., Wasserman W., and Kutner M.H., 1990. Applied linear statistical models, regression, analysis of variance and experimental design, $3^{\text {rd }}$ edition, Irwin publishing, Burr Ridge, Illinois, USA, pp.10.

Ott, L., 1984. An introduction to statistical methods and data analysis, $2^{\text {nd }}$ edition, Duxbury Press, Boston, Massachusetts USA, pp. 280-324. 
Payne, W. V. and Domanski, P. A., 2005. A curve-based mixed system rating method for unitary air conditioners. NISTIR 7225. U.S. Dept. of Commerce. National Institute of Standards and Technology. Gaithersburg, Maryland USA 20899.

Ryan, Thomas P. 1997. Modern regression methods. John Wiley and Sons, Inc. 605 Third Avenue, New York, NY 10158-0012.

Taylor, B. N., and Kuyatt, C. E., 1994. "Guidelines for evaluating and expressing the uncertainty of NIST measurement results", NIST Technical Note 1297, 1994 edition, U.S. Department of Commerce.

Timm, M. L. 1991. "An improved method for calculating refrigerant line pressure drops," ASHRAE Transactions, Vol. 97, No. 1, pp. 194-203. 


\section{APPENDIX C. UNCERTAINTY OF THE MIXED SYSTEM CAPACITY AND SEER}

The methods illustrated here for calculating uncertainty in mixed system capacity and power will produce combined uncertainties larger than the standard propagation of error technique due to the mathematical addition of uncertainties instead of a root-meansquare calculation of uncertainties. All uncertainty calculations assume no statistical correlation between the capacity, power, EER, and SEER. The analysis presented in this section and calculation examples require use of the same confidence level for all linear fits.

\section{C1. A Simplified Calculation of Uncertainty for $Q(95)_{\text {mixed }}$}

The technique for calculating the uncertainty in $Q(95)$ and $P(95)$ explained here assumes that the linear fits have a total uncertainty expressed as a percentage. For example, the $q(95)$ for the condenser and evaporator plus $p(95)$ for the condenser equation would be expressed as:

$$
\begin{array}{rrr}
q_{C D}(95)=\mathrm{C}_{\mathrm{CD}}(95)+\mathrm{D}_{\mathrm{CD}}(95) T_{\text {evap }} & \pm \mathrm{x} \% & \mathrm{C} 1 \\
q_{\text {coil }}=\mathrm{C}_{\text {coil }}+\mathrm{D}_{\text {coil }} T_{\text {evap }} & \pm \mathrm{y} \% & \mathrm{C} 2 \\
p_{C D}(95)=\mathrm{E}_{\mathrm{CD}}(95)+\mathrm{F}_{\mathrm{CD}}(95) T_{\text {evap }} & \pm \mathrm{z} \% & \mathrm{C} 3
\end{array}
$$

Graphically, the linear fit method intersection of the condensing unit and coil capacity linear fits may be seen below in Figure $\mathrm{C} 1$.

The capacity range indicated in Figure $\mathrm{C} 1$ will be the maximum variation in capacity due to the uncertainty in linear fits for the condensing unit and evaporator. This uncertainty will be greater than the uncertainty calculated by a standard propagation of error using summation of variances; therefore, the capacity uncertainty will be a conservative estimate. Likewise, the maximum evaporator exit refrigerant saturation temperature range indicated in Figure $\mathrm{C} 1$ will be greater than that determined from a propagation of error method. This large evaporator saturation temperature range propagates to the calculation of power uncertainty as seen in Figure C2.

The maximum ranges of capacity and power occur along the diagonals of the quadrilateral created by the intersection of the condensing unit and evaporator coil capacity linear fit uncertainty lines. The region within the quadrilateral formed by the intersection of the uncertainty ranges represents all possible evaporator saturated refrigerant temperatures for the given level of uncertainties. The worst case uncertainties for capacity and power (across the diagonals of the quadrilateral) will be considered and used to develop the uncertainty in EER. 


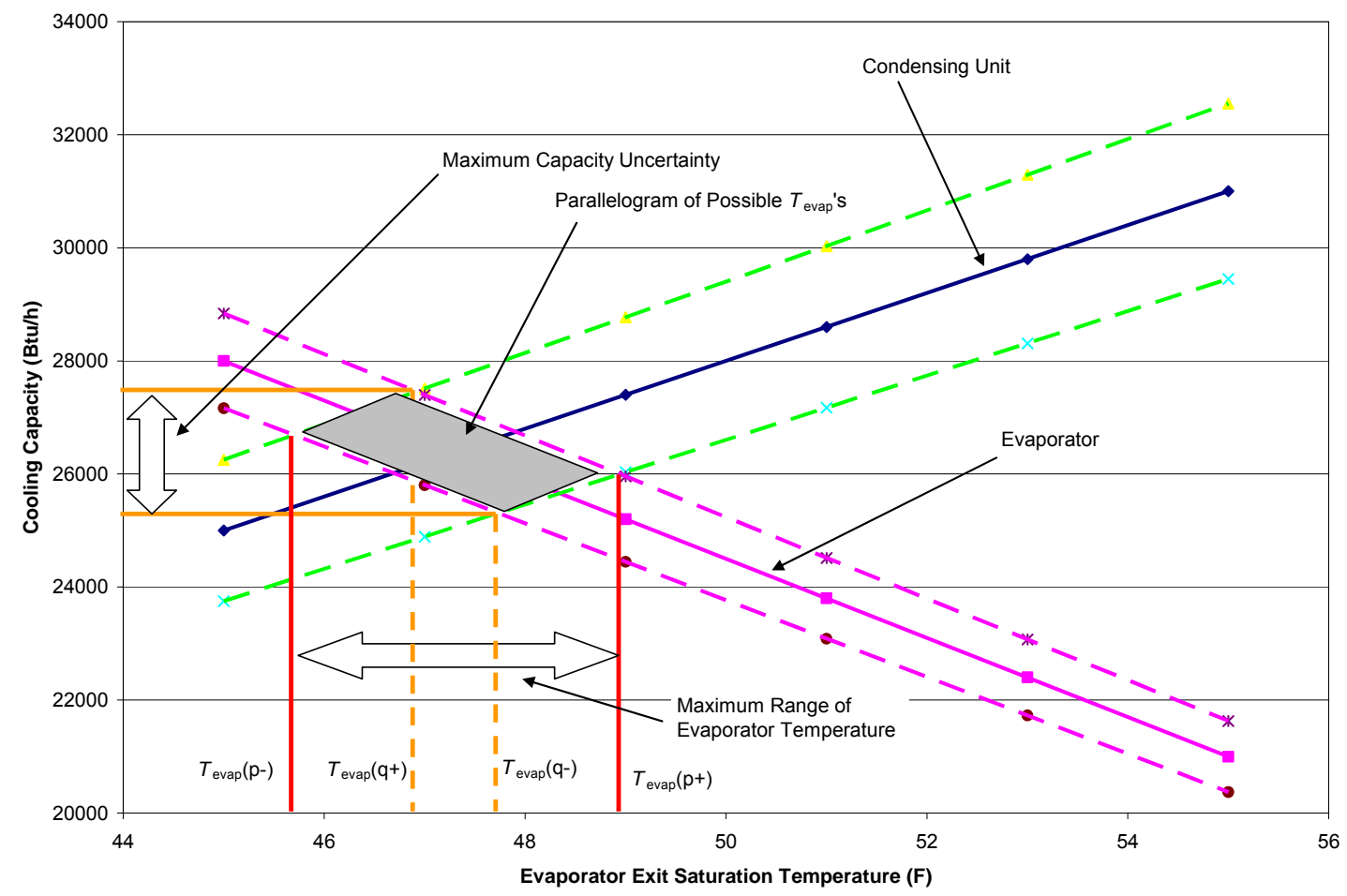

Figure C1. Uncertainty of mixed system capacity due to linear fit uncertainties

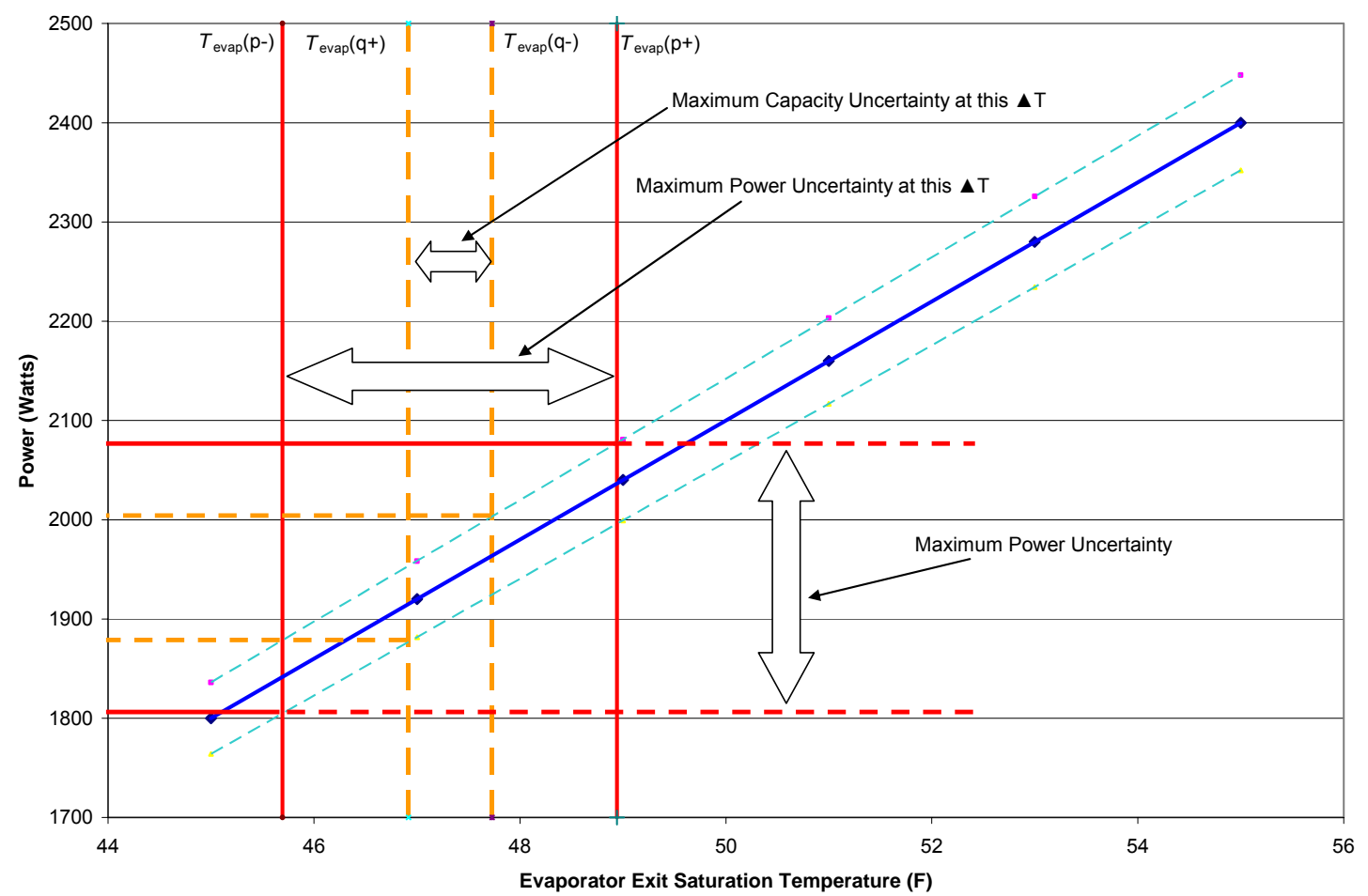

Figure C2. Uncertainty of mixed system condensing unit power due to linear fit uncertainties 
The refrigerant saturation temperature range at the evaporator exit for the maximum capacity uncertainty and maximum power uncertainty occurs at the corners of the quadrilateral in Figure $\mathrm{C} 1$ and may be calculated by the following equations:

$$
\text { Let } \begin{array}{r}
\mathrm{C}_{\mathrm{CD}}(+)=\mathrm{C}_{\mathrm{CD}}(1+\mathrm{x} \%) \text { and } \mathrm{D}_{\mathrm{CD}}(+)=\mathrm{D}_{\mathrm{CD}}(1+\mathrm{x} \%) \\
\mathrm{C}_{\mathrm{coil}}(+)=\mathrm{C}_{\mathrm{coil}}(1+\mathrm{y} \%) \text { and } \mathrm{D}_{\mathrm{coil}}(+)=\mathrm{D}_{\mathrm{coil}}(1+\mathrm{y} \%) \\
\mathrm{C}_{\mathrm{CD}}(-)=\mathrm{C}_{\mathrm{CD}}(1-\mathrm{x} \%) \text { and } \mathrm{D}_{\mathrm{CD}}(-)=\mathrm{D}_{\mathrm{CD}}(1-\mathrm{x} \%) \\
\mathrm{C}_{\mathrm{coil}}(-)=\mathrm{C}_{\mathrm{coil}}(1-\mathrm{y} \%) \text { and } \mathrm{D}_{\text {coil }}(-)=\mathrm{D}_{\mathrm{coil}}(1-\mathrm{y} \%) \\
\mathrm{E}_{\mathrm{CD}}(+)=\mathrm{E}_{\mathrm{CD}}(1+\mathrm{z} \%) \text { and } \mathrm{F}_{\mathrm{CD}}(+)=\mathrm{F}_{\mathrm{CD}}(1+\mathrm{z} \%) \\
\mathrm{E}_{\mathrm{CD}}(-)=\mathrm{E}_{\mathrm{CD}}(1-\mathrm{z} \%) \text { and } \mathrm{F}_{\mathrm{CD}}(-)=\mathrm{F}_{\mathrm{CD}}(1-\mathrm{z} \%) \\
T_{\text {evap }}=\frac{\mathrm{C}_{\text {coil }}-\mathrm{C}_{\mathrm{CD}}}{\mathrm{D}_{\mathrm{CD}}-\mathrm{D}_{\text {coil }}} \\
T_{\text {evap }}(q+)=\frac{\mathrm{C}_{\text {coil }}(+)-\mathrm{C}_{\mathrm{CD}}(+)}{\mathrm{D}_{\mathrm{CD}}(+)-\mathrm{D}_{\text {coil }}(+)} \\
T_{\text {evap }}(q-)=\frac{\mathrm{C}_{\text {coil }}(-)-\mathrm{C}_{\mathrm{CD}}(-)}{\mathrm{D}_{\mathrm{CD}}(-)-\mathrm{D}_{\text {coil }}(-)} \\
T_{\text {evap }}(p+)=\frac{\mathrm{C}_{\text {coil }}(+)-\mathrm{C}_{\mathrm{CD}}(-)}{\mathrm{D}_{\mathrm{CD}}(-)-\mathrm{D}_{\text {coil }}(+)} \\
T_{\text {evap }}(p-)=\frac{\mathrm{C}_{\text {coil }}(-)-\mathrm{C}_{\mathrm{CD}}(+)}{\mathrm{D}_{\mathrm{CD}}(+)-\mathrm{D}_{\text {coil }}(-)}
\end{array}
$$

$T_{\text {evap }}(q+)$ is the refrigerant evaporator temperature that occurs at the intersection of the coil and condensing unit's upper uncertainty \% line. $T_{\text {evap }}(q-)$ occurs at the intersection of the coil and condensing unit's lower uncertainty \% line. These two intersections occur at the largest possible cooling capacity range, but these temperatures do not represent the largest possible range in refrigerant evaporator exit saturation temperature. The largest possible range in refrigerant evaporator exit saturation temperature occurs between $T_{\text {evap }}(p-)$ and $T_{\text {evap }}(p+)$.

The maximum percentage uncertainties in capacity and power may be calculated as follows using the linear fits from the condensing unit or the coil (reference the quadrilateral in Figure $\mathrm{C} 1$ ):

$$
\begin{array}{cr}
q^{+}=q_{\text {coil }}=q_{C D}=\mathrm{C}(+)+\mathrm{D}(+) T \text { evaluated at the upper intersection } & \mathrm{C} 9 \\
q^{-}=q_{\text {coil }}=q_{C D}=\mathrm{C}(-)+\mathrm{D}(-) T \text { evaluated at the lowest intersection } & \mathrm{C} 10 \\
q^{+}\left(T_{\text {evap }}(q+)\right)-q^{-}\left(T_{\text {evap }}(q-)\right)=\Delta q & \mathrm{C} 11 \\
\% \mathrm{U}_{\mathrm{q}}=\frac{\Delta q}{q\left(T_{\text {evap }}\right)} \times 100 \% & \mathrm{C} 12 \\
p^{+}=p_{C D}=\mathrm{E}(+)+\mathrm{F}(+) T \quad \text { evaluated at the right-hand intersection } & \mathrm{C} 13
\end{array}
$$




$$
\begin{array}{cc}
p^{-}=p_{C D}=\mathrm{E}(-)+\mathrm{F}(-) T \text { evaluated at the left-hand intersection } & \mathrm{C} 14 \\
p^{+}\left(T_{\text {evap }}(p+)\right)-p^{-}\left(T_{\text {evap }}(p-)\right)=\Delta p & \mathrm{C} 15 \\
\% \mathrm{U}_{\mathrm{p}}=\frac{\Delta p}{p\left(T_{\text {evap }}\right)} \times 100 \% & \mathrm{C} 16
\end{array}
$$

where $\% U$ = percent uncertainty in capacity or power.

Now the uncertainty in the rated capacity may be found following the same logic as illustrated above, i.e. the linear addition of uncertainties. If the measured indoor unit fan power or indoor volumetric air flowrate has an uncertainty of $\pm u \%$ then the uncertainty on the rated cooling capacity is given by the equations below.

$$
\begin{gathered}
Q_{\text {fan }}=W_{c} P_{\text {fan }} \text { or } Q_{\text {fan }}=W_{c} W_{f} V_{\text {ind }} \\
\left.Q_{\text {fan }}^{+}=Q_{\text {fan }}(1+\mathrm{u} \%) \text { and } Q_{\text {fan }}^{-}=Q_{\text {fan }}(1-\mathrm{u} \%)\right) \\
Q=q\left(T_{\text {evap }}\right)-Q_{\text {fan }} \\
Q^{+}=q^{+}-Q_{\text {fan }}^{-} \text {and } Q^{-}=q^{-}-Q_{\text {fan }}^{+} \\
\% \mathrm{U}_{Q}=\frac{\left(Q^{+}-Q^{-}\right)}{Q} \times 100 \% \\
W_{\mathrm{f}}=\text { flow specific fan power multiplier of } 0.365 \mathrm{~W} / \mathrm{scfm} \\
V_{\text {ind }}=\text { indoor air flow rate of standard air, } \mathrm{scfm}\left(\mathrm{m}^{3} / \mathrm{s}\right)
\end{gathered}
$$

where: $\quad W_{\mathrm{f}}=$ flow specific fan power multiplier of $0.365 \mathrm{~W} / \mathrm{scfm}\left(775 \mathrm{~W} /\left(\mathrm{m}^{3} / \mathrm{s}\right)\right)$ $W_{\mathrm{c}}=3.412 \mathrm{Btu} /(\mathrm{W} \cdot \mathrm{h})(1 \mathrm{~W} / \mathrm{W})$

The uncertainty in the mixed system total power is also given below.

$$
\begin{gathered}
P=p\left(T_{\text {evap }}\right)+P_{\text {fan }} \\
P_{\text {fan }}^{+}=P_{\text {fan }}(1+\mathrm{u} \%)=W_{f} V_{\text {ind }}(1+\mathrm{u} \%) \\
P_{\text {fan }}^{-}=P_{\text {fan }}(1-\mathrm{u} \%)=W_{f} V_{\text {ind }}(1-\mathrm{u} \%) \\
P^{+}=p^{+}+P_{\text {fan }}^{+} \text {and } P^{-}=p^{-}+P_{\text {fan }}^{-} \\
\% \mathrm{U}_{\mathrm{P}}=\frac{\left(P^{+}-P^{-}\right)}{P} \times 100 \%
\end{gathered}
$$

\section{C2. Uncertainty Propagation for SEER $\boldsymbol{R}_{\text {mixed }}$}

The previous section illustrated a simplified linear addition of uncertainties technique for determining the uncertainty in the linear fits. The linear fits for $q(95)$ and $p(95)$ along with fan power are used to calculate the value of $\operatorname{EER}(95)_{\text {mixed. }}$ The value of $\operatorname{EER}(95)_{\text {mixed }}$ is then combined with the matched system quantities to determine the 
rated SEER $R_{\text {mixed. }}$ This section will explore the propagation of error into $E E R_{\text {mixed }}$ and SEER $R_{\text {mixed }}$ brought about by uncertainty in the quantities used to calculate them.

C2.1. EER(95) ${ }_{\text {mixed }}$ Uncertainty Propagation

Equation C28 lists the variables involved in calculating $\operatorname{EER}(95)_{\text {mixed. }}$ The linear fit standard error and the chosen confidence interval (80\%, $90 \%, 95 \%$, etc.) will determine the percentage error for the linear fit as illustrated by Equation $\mathrm{C6}$. One way to illustrate the effects of various percentage errors in capacity and power is to develop a table of error percentages for capacity and power and show how this uncertainty propagates to the uncertainty in EER.

$$
\operatorname{EER}(95)_{\text {mixed }}=\frac{q(95)-3.412 P_{\text {fan,mixed }}}{p(95)+P_{\text {fan,mixed }}}
$$

The uncertainty in EER from Equation C28 may be calculated from Equation C29 (Ott 1984).

$$
\mathrm{U}_{\mathrm{EER}}^{2}=\left(\frac{\partial \mathrm{EER}}{\partial q(95)} \mathrm{U}_{\mathrm{q}(95)}\right)^{2}+\left(\frac{\partial \mathrm{EER}}{\partial p(95)} \mathrm{U}_{p(95)}\right)^{2}+\left(\frac{\partial \mathrm{EER}}{\partial P_{\mathrm{fan}}} \mathrm{U}_{\text {Pfan }}\right)^{2}
$$

where

$$
\begin{aligned}
& \frac{\partial E E R}{\partial q(95)}=\left(p(95)+P_{\text {fan,mixed }}\right)^{-1} \\
& \frac{\partial E E R}{\partial p(95)}=\frac{-\left(q(95)-3.412 P_{\text {fan,mixed }}\right)}{\left(p(95)+P_{\text {fan,mixed }}\right)^{2}} \\
& \frac{\partial E E R}{\partial P_{\text {fan }}}=\frac{-\left(q(95)-3.412 P_{\text {fan,mixed }}\right)}{\left(p(95)+P_{\text {fan,mixed }}\right)^{2}}-\frac{3.412\left(p(95)+P_{\text {fan,mixed }}\right)}{\left(p(95)+P_{\text {fan,mixed }}\right)^{2}} \\
& U_{\text {EER }}=\text { uncertainty in the EER } \\
& U_{q(95)}=\text { uncertainty in } q(95) \\
& U_{p(95)}=\text { uncertainty in p(95) } \\
& U_{\text {Pfan }}=\text { uncertainty in the indoor fan power } \\
& \text { and 3.412 is the conversion from (W) to (Btu/h). }
\end{aligned}
$$

The uncertainty in the EER is a function of the three quantities $q(95), p(95)$, and $P_{\text {fan,mixed }}$ and their respective uncertainties. As an illustration, we will examine a hypothetical system which has an EER of 13.5 and a cooling capacity $(\mathrm{Q}(95))$ of $34458 \mathrm{Btu} / \mathrm{h}(10.09 \mathrm{~kW})$.

Therefore $\quad q(95)=36000 \mathrm{Btu} / \mathrm{h}$

$$
\begin{aligned}
& p(95)=2100 \mathrm{~W} \\
& \mathrm{P}_{\text {fan }}=452 \mathrm{~W} .
\end{aligned}
$$

Table $\mathrm{C} 1$ shows the calculated EER percentage uncertainty for various percentage uncertainties in the capacity, power, and fan power. 
Table C1. EER uncertainty for given uncertainties in capacity and power

\begin{tabular}{|c|c|c|c|c|c|c|}
\hline \multirow{2}{*}{\multicolumn{2}{|c|}{$\bigcup_{\text {Pfan }} 0 \%$}} & \multicolumn{5}{|c|}{$\mathrm{U}_{\mathrm{q}(95)}$} \\
\hline & & $0 \%$ & $1 \%$ & $5 \%$ & $10 \%$ & $20 \%$ \\
\hline \multirow{5}{*}{$U_{p(95)}$} & $0 \%$ & 0.0 & 1.04 & 5.22 & 10.45 & 20.90 \\
\hline & $1 \%$ & 0.82 & 1.33 & 5.29 & 10.48 & 20.91 \\
\hline & $5 \%$ & 4.11 & 4.25 & 6.65 & 11.23 & 21.30 \\
\hline & $10 \%$ & 8.23 & 8.29 & 9.75 & 13.30 & 22.46 \\
\hline & $20 \%$ & 16.46 & 16.49 & 17.27 & 19.49 & 26.60 \\
\hline \multirow{2}{*}{\multicolumn{2}{|c|}{$U_{\operatorname{Pfan}} 1 \%$}} & \multicolumn{5}{|c|}{$\mathrm{U}_{\mathrm{q}(95)}$} \\
\hline & & $0 \%$ & $1 \%$ & $5 \%$ & $10 \%$ & $20 \%$ \\
\hline \multirow{5}{*}{$U_{p(95)}$} & $0 \%$ & 0.22 & 1.07 & 5.23 & 10.45 & 20.90 \\
\hline & $1 \%$ & 0.85 & 1.35 & 5.29 & 10.48 & 20.91 \\
\hline & $5 \%$ & 4.12 & 4.25 & 6.65 & 11.23 & 21.30 \\
\hline & $10 \%$ & 8.23 & 8.30 & 9.75 & 13.30 & 22.46 \\
\hline & $20 \%$ & 16.46 & 16.49 & 17.27 & 19.50 & 26.60 \\
\hline \multirow{2}{*}{\multicolumn{2}{|c|}{$U_{\text {Pfan }} 5 \%$}} & \multicolumn{5}{|c|}{$\overline{U_{q(95)}}$} \\
\hline & & $0 \%$ & $1 \%$ & $5 \%$ & $10 \%$ & $20 \%$ \\
\hline \multirow{5}{*}{$U_{p(95)}$} & $0 \%$ & 1.11 & 1.52 & 5.34 & 10.51 & 20.92 \\
\hline & $1 \%$ & 1.38 & 1.73 & 5.40 & 10.54 & 20.94 \\
\hline & $5 \%$ & 4.26 & 4.39 & 6.74 & 11.28 & 21.33 \\
\hline & $10 \%$ & 8.30 & 8.37 & 9.81 & 13.35 & 22.48 \\
\hline & $20 \%$ & 16.50 & 16.53 & 17.30 & 19.53 & 26.62 \\
\hline
\end{tabular}

Table $\mathrm{C} 1$ shows that the condensing unit power uncertainty and the capacity uncertainty propagate equally into the uncertainty in EER. Fan power uncertainty carries little weight for the values selected above.

C2.2. SEER mixed Uncertainty Propagation

Equation $\mathrm{C} 30$ is used to calculate the SEER of the mixed system. It utilizes the matched system rated SEER and EER at A Test conditions. These values are published by most manufacturers. EER(95) mixed is calculated using the linear fit procedure with $\mathrm{F}_{\text {exp }}$ determined according to Section 4.4. The following will illustrate the propagation of error into the mixed system SEER by considering various uncertainty percentages in the independent quantities of Equation C30.

$$
\operatorname{SEER}_{\text {mixed }}=\operatorname{SEER}_{\text {matched }} \frac{\operatorname{EER}(95)_{\text {mixed }}}{\operatorname{EER}(95)_{\text {matched }}} F_{\text {exp }}
$$

The mixed system SEER is a function of four independent quantities:

1. SEER matched $_{\text {matc }}$

2. $\operatorname{EER}(95)_{\text {matched }}$

3. $\operatorname{EER}(95)_{\text {mixed }}$

4. $F_{\exp }$ 
The uncertainty in SEER $R_{\text {mixed }}$ may be calculated as follows:

$$
\begin{aligned}
& \mathrm{U}_{\text {SEERmixed }}^{2}=\left(\frac{\partial S E E R_{\text {mixed }}}{\partial S E E R_{\text {matched }}} U_{\text {SEERmatched }}\right)^{2}+\left(\frac{\partial S E E R_{\text {mixed }}}{\partial E E R(95)_{\text {matched }}} U_{\text {EER(95)matched }}\right)^{2}+\ldots \ldots \ldots \ldots \ldots \ldots \\
& \left(\frac{\partial S E E R_{\text {mixed }}}{\partial \operatorname{EER}(95)_{\text {mixed }}} U_{\text {EER }(95) \text { mixed }}\right)^{2}+\left(\frac{\partial S E E R_{\text {mixed }}}{\partial \mathrm{F}_{\text {exp }}} U_{\text {Fexp }}\right)^{2}
\end{aligned}
$$

where

$$
\begin{aligned}
& \frac{\partial S E E R_{\text {mixed }}}{\partial S E E R_{\text {matched }}}=\frac{\operatorname{EER}(95)_{\text {mixed }}}{\operatorname{EER}(95)_{\text {matched }}} F_{\text {exp }} \\
& \frac{\partial S E E R_{\text {mixed }}}{\partial E E R(95)_{\text {matched }}}=-S E E R_{\text {matched }} \frac{\operatorname{EER}(95)_{\text {mixed }}}{\operatorname{EER}(95)^{2}{ }_{\text {matched }}} F_{\text {exp }} \\
& \frac{\partial S E E R_{\text {mixed }}}{\partial E E R(95)_{\text {mixed }}}=\frac{\operatorname{SEER} R_{\text {matched }}}{\operatorname{EER}(95)_{\text {matched }}} F_{\text {exp }} \\
& \frac{\partial S E E R_{\text {mixed }}}{\partial F_{\text {exp }}}=S E E R_{\text {matched }} \frac{\operatorname{EER}(95)_{\text {mixed }}}{\operatorname{EER}(95)_{\text {matched }}}
\end{aligned}
$$

$\mathrm{U}_{\text {SEERmatched }}=$ uncertainty in the matched system rated SEER

$U_{\text {EER(95)matched }}=$ uncertainty in the A Test EER of the matched system

$U_{\text {EER(95)mixed }}=$ uncertainty in the calculated mixed system EER(95)

$\mathrm{U}_{\mathrm{Fexp}}=$ uncertainty in the expansion device/fan delay correction factor

As an illustration, we will examine a hypothetical system which has the following

\begin{tabular}{|c|c|c|c|c|c|}
\hline \multicolumn{5}{|c|}{ Squared UncertaintyTerms from Equation C31 } & \multirow{2}{*}{$\begin{array}{c}\% U \\
\text { SEER }\end{array}$} \\
\hline $\begin{array}{c}\text { Given } \\
\% U\end{array}$ & SEER $R_{\text {matched }}$ & $\mathrm{EER}_{\text {mixed }}$ & $\mathrm{EER}_{\text {matched }}$ & $F_{\exp }$ & \\
\hline $1 \%$ & 0.02042 & 0.02042 & 0.02042 & 0.02042 & 2.0 \\
\hline $5 \%$ & 0.51056 & 0.51056 & 0.51056 & 0.51056 & 10.0 \\
\hline $10 \%$ & 2.04225 & 2.04225 & 2.04225 & 2.04225 & 20.0 \\
\hline $20 \%$ & 8.16898 & 8.16898 & 8.16898 & 8.16898 & 40.0 \\
\hline $50 \%$ & 51.05613 & 51.05613 & 51.05613 & 51.05613 & 100.0 \\
\hline
\end{tabular}
characteristics:

$$
\begin{aligned}
& \text { SEER }{ }_{\text {matched }}=13 \\
& \text { EER }(95)_{\text {matched }}=14 \\
& \operatorname{EER}(95)_{\text {mixed }}=15 \\
& F_{\text {exp }}=1.026 \text { from Table } 1 \text { and Table } 2 \text { going from an A-type matched } \\
& \quad \text { to C-type mixed system } \\
& \text { SEER }{ }_{\text {mixed }}=14.291 .
\end{aligned}
$$

Table C2 shows the percentage uncertainty in SEER mixed $_{\text {for }}$ the given uncertainties in the four independent quantities.

Table C2. SEER mixed $_{\text {uncertainty }}$ 
Table C2 shows the contribution of each uncertainty term to the sum of squares for the total uncertainty. The row indicates the percentage uncertainty in the four independent variables. The column indicates the squared terms as shown on the right-hand-side of Equation C31. SEER $R_{\text {matched, }} E E R_{\text {mixed }}$, EER $R_{\text {matched }}$ and $F_{\text {exp }}$ uncertainties propagate equally because these quantities are of the same order of magnitude in Equation C31 and are multiplicative in Equation C30. 